\title{
Islet Cell Autoantigens in Insulin-dependent Diabetes
}

\author{
Mark A. Atkinson and Noel K. Maclaren \\ Department of Pathology and Laboratory Medicine, College of Medicine, University of Florida, Gainesville, Florida 32610
}

\section{Introduction}

Although nearly two decades have passed since the first description of autoantibodies in persons with insulin-dependent diabetes (IDD), ${ }^{1}$ the islet cell autoantigens that serve as targets in this autoimmune disorder have only recently been identified. In fact, so many autoantigens have been described in this disorder that it has become increasingly difficult to identify those that are the most important for broad-based clinical investigations, and those (if any) that are involved in the primary immunological events of the autoimmune disease process. Whereas the majority of these autoantigens have been identified by their reactivity with sera from IDD patients, studies of the proliferative responses of peripheral blood monocytes obtained from IDD patients have also been useful in this regard. Table I lists a current compilation of the most widely recognized islet cell autoantigens of IDD. In this Perspectives review, we have emphasized the biochemical and immunological characterizations of the IDD-associated autoantigens but not the frequency of detection of their respective autoantibodies, since in many instances the latter information remains subject to interlaboratory variation. The identification of islet cell autoantigens holds promise for improving our understanding of the pathogenesis of IDD, the development of diagnostics for predicting its clinical onset, and the design of specific therapies for the prevention of the disease.

\section{The pancreatic islet cell}

The human pancreas is an organ with both exocrine and endocrine functions. This lobular gland has numerous acini and ducts, held together by a network of connective tissue within a discreet capsule. The exocrine pancreas function involves the synthesis, storage, and secretion of digestive enzymes. Located among the exocrine pancreas is a series of specialized endocrine cells that are organized into the islets of Langerhans. An adult pancreas contains between $10^{5}$ and $2 \times 10^{6}$ islets, with individualized islets comprised of a few hundred to several

Address correspondence to Dr. Mark A. Atkinson, Department of Pathoiogy, Box J-275, JHMHC, Gainesville, FL 32610. 1993.

Received for publication 9 April 1993 and in revised form 13 July

1. Abbreviations used in this paper: GABA, gamma-aminobutryic acid; GAD, glutamic acid decarboxylase; hsp, heat shock protein; IAA insulin autoantibody; ICA, islet cell cytoplasmic autoantibody; ICSTA, islet cell stimulatory autoantibody; IDD, insulin-dependent diabetes; PIAA, proinsulin autoantibody; SLMV, synaptic-like microvesicles.

J. Clin. Invest.

(C) The American Society for Clinical Investigation, Inc.

0021-9738/93/10/1608/09 \$2.00

Volume 92, October 1993, 1608-1616 thousand individual endocrine cells. Most islets have a diameter of $100-200 \mu \mathrm{m}$, and collectively they constitute $1-2 \%$ of the total volume of the pancreas. Each islet has a fine capillary network, and is encapsulated by collagen.

An islet is composed of at least four endocrine cell types, including: (a) beta cells: insulin (5,800 daltons, 51 amino acids)-secreting cells constituting the core of the islet for $\sim 60 \%$ of the islet volume; $(b)$ alpha cells: glucagon $(3,485$ daltons, 29 amino acids)-secreting cells distributed either in the core or around the islet periphery and forming $\sim 10-20 \%$ of the islet volume; $(c)$ delta cells: somatostatin (1,640 daltons, 14 amino acids)-secreting cells located variably within the islet that comprise some 5-10\% of the islet volume; and $(d)$ pancreatic polypeptide (4,200 daltons, 36 amino acids)-secreting cells that although normally are located within the islet periphery (10-20\%), can also be found scattered within the exocrine parenchyma. The distribution of the endocrine cell types within the islets and throughout the pancreas is not random but represents a precise organ topography. The posterior duodenal portion of the gland contains islets with many pancreatic polypeptide cells and alpha cells, whereas islets within the head, tail, and body of the pancreas contain proportionally more beta cells.

Beta cells are similar to neurons in that these cells have little reproductive ability and possess a mechanism for the release of stored secretory products via exocytosis. The secretion of these proteins represents the end point of a pathway involving production, packaging, storage of hormones in granules proximal to their release site, and their release by exocytosis after a specific tropic stimulus (Fig. 1). Beta cells have two types of vesicles: secretory vesicles, which contain insulin, carboxypeptidase $H$, betagranin, pancreastatin, and cathepsin $B$; and synaptic-like microvesicles (SLMVs), which contain gammaaminobutryic acid (GABA), glutamate decarboxylase (GAD), and synaptophysin. These two vesicle systems have analogous counterparts in neurons with respect to their neurotransmittercontaining small synaptic vesicles (analogous to SLMVs) and their large dense core-containing vesicles (analogous to insulin secretory granules). The beta cell stores thousands of secretory granules containing insulin-zinc hexamers. Beta cells secrete insulin in response to an increase in capillary blood glucose concentrations. Necessary prerequisites for this process include glucose uptake via a glucose transporter as well as glucose metabolism within beta cells. It is believed that after specific transport of glucose, a stimulated glucokinase will express a specific hexokinase activity resulting in a signal to the insulin secretory granule to fuse with the plasma membrane, thus allowing the release of insulin into the blood stream.

\section{Islet cell cytoplasmic autoantigens}

The initial description of islet cell autoantibodies (ICA) provided strong evidence for an autoimmune etiology and patho- 
Table I. Islet Cell Autoantigens

of Insulin-dependent Diabetes

\begin{tabular}{|c|c|}
\hline Autoantigen & Characteristics \\
\hline Sialoglycolipid & $\begin{array}{l}\text { Target of ICA in humans, GM2-1, } \\
\text { non-beta cell specific }\end{array}$ \\
\hline Glutamate decarboxylase & $\begin{array}{l}\text { Target of } 64-\mathrm{kD} \text { antigen/GAD antibody } \\
\text { in humans and animal models of } \\
\text { IDD, two forms (GAD } 65 \text { and } 67 \text { ), } \\
\text { cellular immune antigen, synaptic } \\
\text { like microvesicle protein, disease- } \\
\text { modifying antigen }\end{array}$ \\
\hline Insulin & $\begin{array}{l}\text { Target of IAA in humans and non-obese } \\
\text { diabetic (NOD) mice, cellular } \\
\text { immune antigen, disease-modifying } \\
\text { antigen }\end{array}$ \\
\hline Insulin receptor & $\begin{array}{l}\text { Target of autoantibodies in humans, } \\
\text { determined by bioassay }\end{array}$ \\
\hline $38 \mathrm{kD}$ & $\begin{array}{l}\text { Target of } 38-\mathrm{kD} \text { antigen in humans, } \\
\text { induced by cytomegalo virus, } \\
\text { localized to insulin secretory granules, } \\
\text { cellular immune antigen, multiple } \\
\text { antigens of this molecular mass? }\end{array}$ \\
\hline Bovine serum albumin & $\begin{array}{l}\text { Target of BSA antibody, antigen in } \\
\text { humans and animal models of IDD, } \\
\text { contains ABBOS peptide, has } \\
\text { molecular mimic in beta cell p69 } \\
\text { protein (PM-1), disease-modifying } \\
\text { antigen }\end{array}$ \\
\hline Glucose transporter & $\begin{array}{l}\text { Target of autoantibodies in humans, } \\
\text { inhibit glucose stimulation, GLUT-2 } \\
\text { directed? }\end{array}$ \\
\hline hsp 65 & $\begin{array}{l}\text { Target of autoantibodies and cellular } \\
\text { immunity in NOD mice, disease- } \\
\text { modifying antigen, contains p } 277 \\
\text { peptide }\end{array}$ \\
\hline Carboxypeptidase $\mathrm{H}$ & $\begin{array}{l}\text { Target of autoantibodies in humans, } \\
\text { identified by immunoscreening of } \\
\text { islet cDNA, insulin secretory granule } \\
\text { protein }\end{array}$ \\
\hline $52 \mathrm{kD}$ & $\begin{array}{l}\text { Target of autoantibodies in humans and } \\
\text { NOD mice, molecular mimic with } \\
\text { Rubella virus }\end{array}$ \\
\hline ICA $12 / \mathrm{ICA} 512$ & $\begin{array}{l}\text { Target of autoantibodies in humans, } \\
\text { identified by immunoscreening of } \\
\text { islet cDNA, } 512 \text { homology to CD45 }\end{array}$ \\
\hline $150 \mathrm{kD}$ & $\begin{array}{l}\text { Target of autoantibodies in humans, } \\
\text { beta cell specific, membrane } \\
\text { associated }\end{array}$ \\
\hline RIN polar & $\begin{array}{l}\text { Target of autoantibodies in humans and } \\
\text { NOD mice present on insulinoma cells }\end{array}$ \\
\hline
\end{tabular}

genesis of IDD (1). ICA were defined as "cytoplasmic" by their ability to react to antigen(s) located within the cytoplasmic compartment of all endocrine cells of the pancreatic islet. Although the assay for ICA detection in human sera has been modified through the years since its original description, the procedure most often used today still involves the indirect immunofluorescence of cryosectioned human pancreas (Fig. 2).
Hundreds of studies describing ICA in various populations have been reported that collectively suggest that at least $0.1-$ $0.3 \%$ of normal (healthy) controls and $70-80 \%$ of new onset IDD patients are ICA positive (2-4). The frequency of ICA in nondiabetic relatives of IDD probands is $2-5 \%$, while their presence indicates an age- and titer-dependent increase in risk of IDD. Multiple studies of IDD patients suggest that the frequency of ICA decreases with increasing duration of overt disease, consistent with an antigen-driven immunological process underlying their genesis.

All of the autoantigens to which the ICA are reactive have not yet been fully characterized. Initial studies suggested that the target antigen of ICA was a sialic acid-containing glycolipid (5). This claim was based on: ( $a$ ) the removal of ICA antigenic reactivity from tissue sections when processed by alcohol-based fixatives; $(b)$ a similarity in biochemical properties of antigens recognized by antiganglioside monoclonal antibodies to those of ICA; and $(c)$ an observation that ICA binding could be blocked by a glycolipid extract of human pancreas that migrates as a monosialoganglioside (6). Whereas glycolipids extracted from whole pancreas are primarily composed of GM3 and GD3 gangliosides, islet cells also are enriched in monosialogangliosides (including GM2), and the ICA antigen reportedly migrated as a specific ganglioside on thin layer chromatography between GM2 and GM1 (7).

The putative sialoglycolipid nature of ICA has, however, needed to be readdressed due to the findings that some ICA are in fact reactive to GAD. The ICA associated with the rare neurological disease Stiff-Man syndrome, which is itself associated with IDD, have clearly been identified to predominantly represent an anti-GAD response (8), whereas the ICA in IDD patients represent a diverse subset of autoantibodies (9-11). Recombinant GAD can compete/interfere with the ICA reactivity associated with IDD in the absence of Stiff-Man syndrome (11), and these anti-GAD ICA, as compared with non-GAD ICA actually identify a subpopulation of individuals with a lower rate of progression to IDD than that expected in general for ICA positive persons $(10,11)$, possibly because non-GAD ICA occur secondarily to beta cell damage. Others have classified ICA according to their ability to react with antigens specifically within beta cells, or with antigens within all islet endocrine cells $(9,10)$. Further characterization of the ICA-reactive antigens is necessary, and is the subject of current research attention.

\section{4- $k D / G A D$ autoantigen}

Immunoprecipitation of detergent lysates of metabolically labeled islet cells with sera from IDD patients resulted in the identification of a 64-kD autoantigen (Fig. 3) (12). These 64kD-reactive autoantibodies normally occur before the onset of IDD (13) and, among nondiabetic relatives of patients with IDD, they have been suggested to be the best predictive autoantibody marker for impending IDD (14). Nearly a decade after its initial description, the $64-\mathrm{kD}$ protein was biochemically identified as GAD (15).

Two forms of GAD with molecular masses of 65 and $67 \mathrm{kD}$ (GAD 65 and GAD 67) exist (16). These two proteins are encoded by different genes located on different chromosomes (human chromosome 2 for GAD 65, and 10 for GAD 67). The amino acid sequences of the two GADs are $\sim 70 \%$ homologous, and both proteins contain a binding site for pyridoxal 


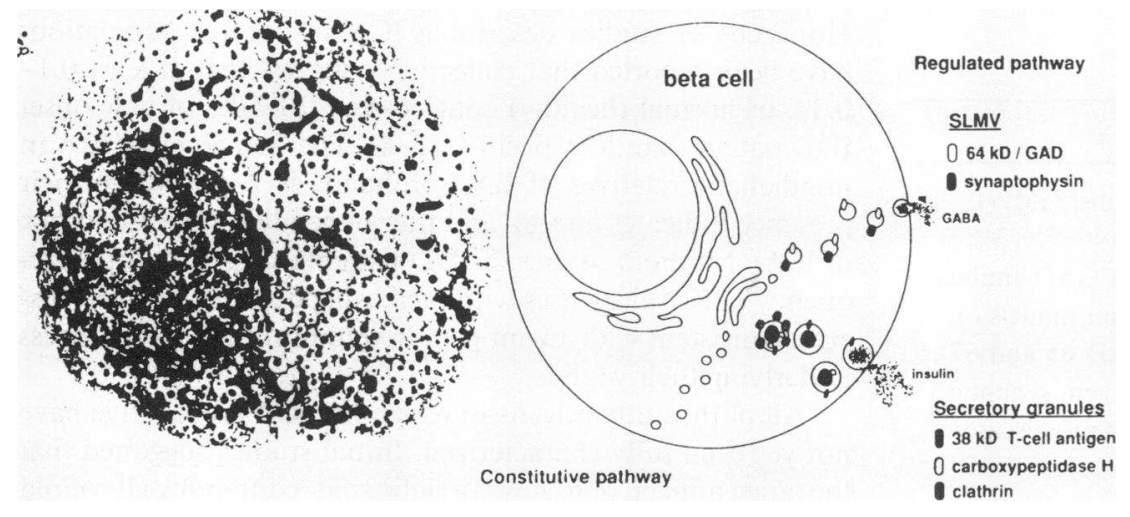

Figure 1. (Left) Transmission electron microscopical picture of a single pancreatic beta cell, featuring granules with insulin crystals in the secretory granules (courtesy of Dr. P. In't Veld, Vrije Universiteit Brussels); (right) schematic representation of secretory pathways of pancreatic beta cells. phosphate, a cofactor necessary for the enzymatic activity of GAD. GAD catalyses the formation of the inhibitory neurotransmitter GABA from glutamine. Within the neurological system, GAD 65 predominates within the central nervous system while GAD 67 predominates in peripheral nerves. Both forms of GAD have been identified within the GABAnergic neurons of the brain as well as in the pancreatic islet cells, however, other reported locations (some controversial) include the testes, ovary, oviduct, and adrenal medulla (17). Both GAD 65 and GAD 67 have been identified in the islet cells and brain of the same species, and amino acid sequence analysis as well as biochemical characterization (18) have so far revealed no differences between the brain and the pancreatic islet forms of these genes. Within the islet, GAD may have a role in the inhibition of somatostatin and glucagon secretions, as well as in regulating insulin secretion and proinsulin synthesis. Initial reports indicated that GAD was predominantly observed in beta cells and primarily stored within the SMLVs (1.9). However, more recent studies suggest a strong degree of species and islet endocrine cell variation in GAD expression $(20,21)$ Specifically, rat islets were shown to contain both isoforms of GAD, whereas human islets expressed only GAD 65 , and GAD expression within islets was not limited to the beta cells $(20,21)$.

Recombinant produced GADs have been used to detect
GAD 65 and GAD 67 autoantibodies in persons with or at risk for IDD $(21,22)$. One study $(22)$ reported that the anti-64-kD response was primarily composed of an anti-GAD 65 activity, that multiple autoantibody epitopes were present within GAD (although none were identified within the $\mathrm{NH}_{2}$-terminal 200 amino acids), that a region of GAD has a homologous protein sequence with the $\mathrm{P} 2-\mathrm{C}$ protein of coxsackie $\mathrm{B} 4$ virus, and that some forms of neuropathy in IDD may be associated with antiGAD immunity. Evidence of lymphocyte-directed immunity toward GAD has also been shown (23) and was strongly associated with IDD.

\section{Insulin}

Insulin autoantibodies (IAA) have been second only to ICA in terms of research interest, most likely due to the ready availability of insulin as a purified antigen. These spontaneously arising endogenous autoantibodies were first described by Palmer et al. (24) to be present in the sera of $\sim 20 \%$ of newly diagnosed IDD patients before they received any insulin therapy. Modification of assay conditions led not only to an increase in their frequency of identification ( $\sim 50 \%$ of new onset patients), but also to a series of interesting observations. IAA are highly associated with both ICA and reportedly the HLA-DR4 phenotype, while their presence in ICA-positive nondiabetic persons re-

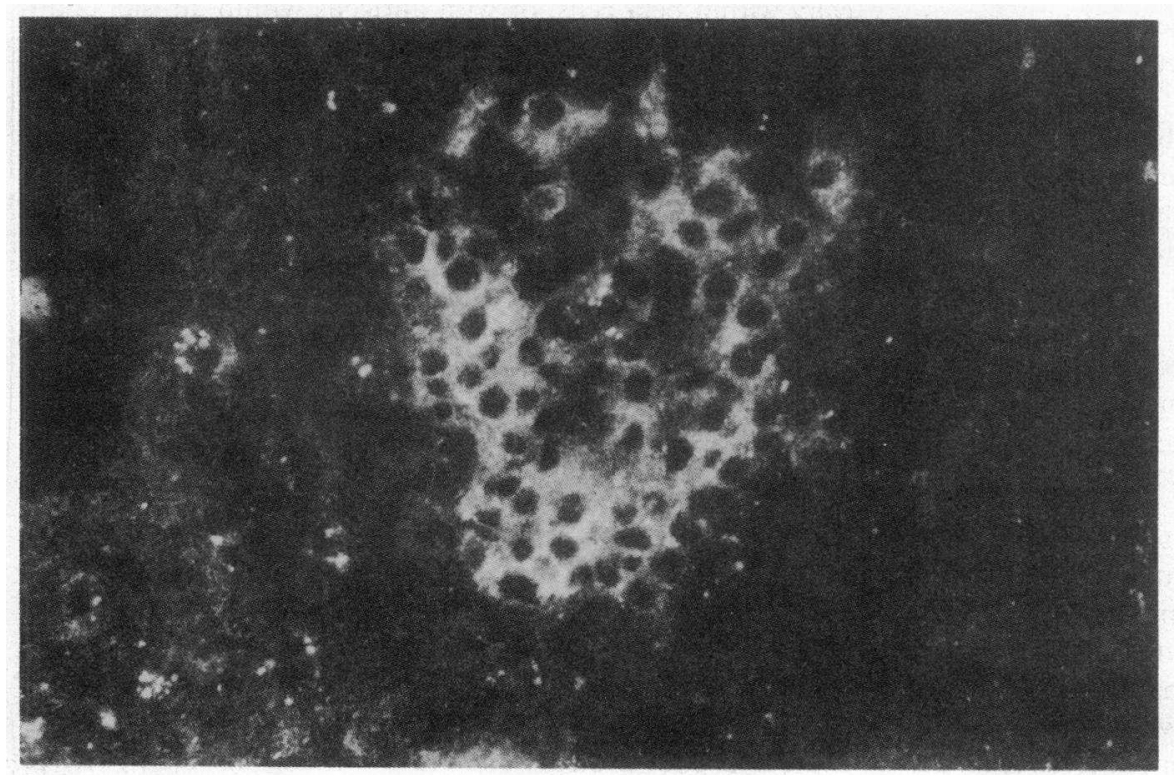

Figure 2. Islet cell cytoplasmic autoantibody reactivity from human IDD sera with cryocut human pancreas. 


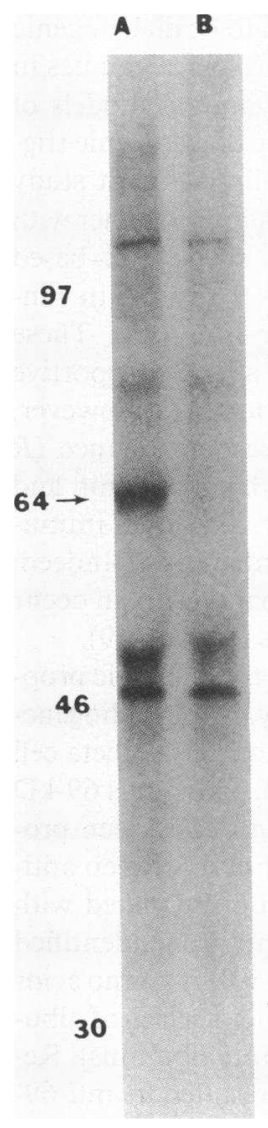

Figure 3. Immunoprecipitation of $64 \mathrm{~K} / \mathrm{GAD}$ autoantigen from human islet cells with sera from IDD patient (lane $A$ ), and absence from control immunoprecipitation (lane $B$ ).

sults in a significantly higher risk of beta cell insufficiency (25). Other studies in high-risk groups have also identified that the two autoantibodies (IAA and ICA) in a single person confer a much greater risk for their subsequent IDD development than does either marker alone (26). Insulin autoantibodies appear to be strikingly and inversely correlated with age in both new-onset IDD patients and their high-risk nondiabetic relatives (27). These data suggest that elevated IAA levels in younger patients may reflect their generally faster rate of islet cell destruction and more rapid progression to IDD than seen in adults. It should, however, be acknowledged that IAA, when found in the absence of ICA, has only low predictive value for progression to IDD.

There are several possible explanations as to why patients generate autoantibodies to insulin before they develop IDD. Islet cells undergoing autoimmune lysis may release immunogenic fragments and/or prepro- or proinsulins that could induce a secondary immunization depending on differences in the HLA class II phenotypes associated with IDD. Alternatively, they may arise de novo as part of the autoimmune response that initiates islet cell lysis. Whether IAA have any direct role in the pathogenesis of IDD remains to be proven, but their early appearance in the natural history of IDD and their correlation with islet cell destruction certainly does not preclude this possibility. Indeed, immunological tolerance to insulin induced by oral feedings of porcine insulin to NOD mice can significantly delay their onsets of diabetes (28).

Although IAA have been investigated extensively for their predictive value, specificity for disease, and assay development, only a few reports exist regarding epitope recognition of insulin by IAA. The most extensive work examined IAA in terms of their species specificity and fragment identity (29). Whereas $50 \%$ of IAA sera recognized whole human insulin, these same sera failed to bind to porcine or bovine insulins, but also bind human B chain but not porcine B chain or desalinated porcine insulin, suggesting that position B30 was vital to epitopic recognition. The remaining $50 \%$ of sera bound to all aforementioned species of insulin. These authors further reported that unlike IAA, antiinsulin antibodies induced by exogenous insulin administration recognize epitopes involving either the A chain exclusively or a conformational epitope involving both chains. One human monoclonal antibody developed from an IDD patient receiving insulin therapy recognized intact native insulin but not individual A or B chains (30). An analysis (31) of another patient with the insulin autoimmune syndrome revealed a monoclonal antibody response (IgG1, lambda light chain) with a single binding affinity for a determinant at the asparagine at B chain (B3). Some insulin autoimmune patients, as well as IDD patients, were also reported (32) to have islet cell stimulatory autoantibodies (ICSTA). These ICSTA were reported to stimulate the release of insulin both in vitro and in vivo by some five- to eightfold stimulation from basal levels, and to increase the level of preproinsulin mRNA (32). A series of five monoclonal antibodies to human insulin were generated (33) that showed multiple epitope specificities for both the A chain (A4, A8-10) as well as the B chain (B30). The epitopic specificities for two of these monoclonals were so sensitive that substitutions of hydroxyl and methyl groups on B30 affected binding of the antibodies.

With respect to proinsulin autoantibodies (PIAA), the immediate precursor form of insulin, recent reports have claimed that PIAA were more closely associated to IDD than IAA (34). Specifically, new onset patients were observed to have PIAA more often than IAA, however, every IAA was also PIAA positive. On the other hand some PIAA were not reactive to native insulin, suggesting that PIAA may represent antibodies to A, B, and $C$ chain determinants and epitopes that have been lost during the conversion of proinsulin to insulin. It was also interesting that none of the IAA sera could be rendered antibody negative by preclearance with proinsulin. This suggests that few IAA are directed against determinants that were not accessible in the precursor protein proinsulin. These results could be explained if proinsulin, rather than insulin, was the immunogen that induced both PIAA and IAA. Indeed, some proinsulin is secreted physiologically by beta cells (35), and elevated levels of proinsulin have been reported in relatives of those with disease (36).

At least two reports exist describing $\mathrm{T}$ lymphocyte responses to insulin as an autoantigen $(37,38)$. In one study, cellular responses to human insulin were present in nearly all (89\%) ICA-positive first degree relatives of IDD patients (37). A second study (38) has shown that antiinsulin peripheral blood mononuclear cell responses exist in both preonset and newly diagnosed IDD patients. However, since the level of antiinsulin activity (i.e., cellular proliferation) was lower than responses to an undefined islet cell antigen preparation, the authors proposed that insulin (soluble) is not the major islet cell antigen in measurements of $T$ lymphocyte proliferation. Finally, the authors demonstrated that the cellular recognition of insulin shows species specificity within these patients, a situation simi- 
lar to that observed with cellular responses from insulin-treated diabetics (39). In fact, the latter studies claimed that cellular recognition of insulin showed a fine specificity for one or two amino acids (cell lines derived from patients treated with beef insulin only responded to pork insulin peptides that shared homology with beef sequences). Finally, autoantibodies to insulin receptors have also been reported in sera from patients with IDD, and were identified through their inhibitory effect of insulin binding to its receptor (40) These insulin receptor autoantibodies were proposed to arise as antiidiotypes of IAA, however, follow-up studies measuring direct serum binding to isolated insulin receptors suggested that these autoantibodies are infrequent findings in IDD (41).

\section{8- $k D$ autoantigen}

The initial report of anti-38-kD immunity dates back to the studies of the 64-kD autoantigen, which showed that some IDD sera immunoprecipitated a $38-\mathrm{kD}$ protein from human islet cells (12). Because of the relative low frequency of autoantibodies to this protein in comparison with other autoantibodies in new-onset IDD patients, it was the subject of only limited research interest. However, several recent reports have rekindled interest to resolve its identity. A series of islet cell-reactive $T$ cell clones from the peripheral blood mononuclear cells were developed from two recent onset IDD patients, in order to identify the biochemical nature of islet cell autoantigens involved in islet cell autoimmunity (42). In those studies, insulinoma-derived antigens stimulated the proliferation of CD4+ T cell clones after interaction with autologous antigen-presenting cells, a response that was inhibited by anti-HLA DR antibodies. Using subcellular fractionation of insulinoma cells, these same investigators suggested that the antigen inducing the proliferative response was a $38-\mathrm{kD}$ component of the insulinoma secretory granule (43). The cellular distribution of the $38-\mathrm{kD}$ antigen recognized by the $\mathrm{T}$ cell clones showed a common expression limited to neuroendocrine tissues that share the property of storage of bioactive polypeptides in intracellular vesicles, and their secretion by an exocytotic mechanism (e.g., insulinoma, neuroblastoma, pituitary, adrenal). Other tissues, such as the thyroid, gastric fundus, fibroblasts, liver, lung, heart muscle, skeletal muscle, and exocrine pancreas, provoked little or no reactivity by $38-\mathrm{kD}$-reactive $\mathrm{T}$ cells. Follow-up studies showed that peripheral blood mononuclear cells obtained from a majority of new onset IDD patients proliferate in vitro when appropriately presented with $38-\mathrm{kD}$ secretory granule preparations (44).

\section{Bovine serum albumin}

Since genetic factors alone cannot explain the $50-75 \%$ discordance rate of disease between affected probands and their nondiabetic siblings and/or twins, environmental factors have been proposed to be important to the etiopathogenesis of disease. Environmental influences could act through a number of mechanisms (45). Insulitis could be triggered by molecular mimicry between an environmental antigen and an islet cell autoantigen. Dietary indiscretions could also lead to an increase of insulin requirements provoking beta cell activity and augmenting the antigenicity of these cells provoking or exacerbating beta cell autoimmunity. Finally, environmental viruses or toxins could be directly harmful to beta cells and provoke secondary immune responses.

For years, researchers have pointed toward immunity against albumin as a potential environmental link to IDD, with bovine milk proteins in particular suggested to be diabetogenic triggers based upon epidemiological and serological studies in humans and serological/dietary studies of animal models of IDD. Many of these models propose that the diabetogenic triggering event occurs early in life. Specifically, a recent study suggested that prolonged breast feeding of infants together with a corresponding delay in their exposure to cow's milk-based formulas significantly reduced the diabetes frequency in Finnish families at increased genetic risk for IDD (46). These breast feeding studies remain controversial as both supportive and nonsupportive claims have been reported (47). However, on a worldwide basis, there appears to be concordance $(R$ $=0.96$ ) between the milk consumption of the population and the incidence rates for IDD (48). However, studies of immunity to BSA in humans have been quite controversial. Indeed, problems in immunoassays of islet cell autoantigens can occur due to ready adherence of BSA to islet cells in vitro (49).

Recent work has sought to identify both the antigenic properties of BSA and to determine its role, if any, in the pathogenesis of IDD. Anti-BSA antibodies that bind to a $69-\mathrm{kD}$ beta cell surface protein have been reported (50-52). Since, this $69-\mathrm{kD}$ protein was inducible by gamma interferon, it has been proposed that it might be the "environmental link" between antiBSA immunity and the beta cell destruction associated with IDD (Fig. 4). Further studies (52) by that same group identified a small peptide region termed "ABBOS" (pre-BSA amino acids 152-168) that was in major variance to other species of albumin (including human, rat, and mouse serum albumins). Remarkably, immunization with this peptide resulted in anti-69$\mathrm{kD}$ beta cell antibodies. The most recent studies by this group suggested that all IDD patients have increased levels of BSA antibodies, and that most of these can be explained by anti-ABBOS activity (52). This area of antigenicity is under active investigation because of the strong hypothetical link between environmental agents and immunological formation of disease.

\section{Glucose transporter/inhibitory antibodies}

Because glucose-stimulated insulin secretion is selectively impaired in humans with IDD, the role of the glucose transporter of islet cells as a target autoantigen of IDD has been investigated (53). In one study, some $96 \%$ of purified IgG from new-

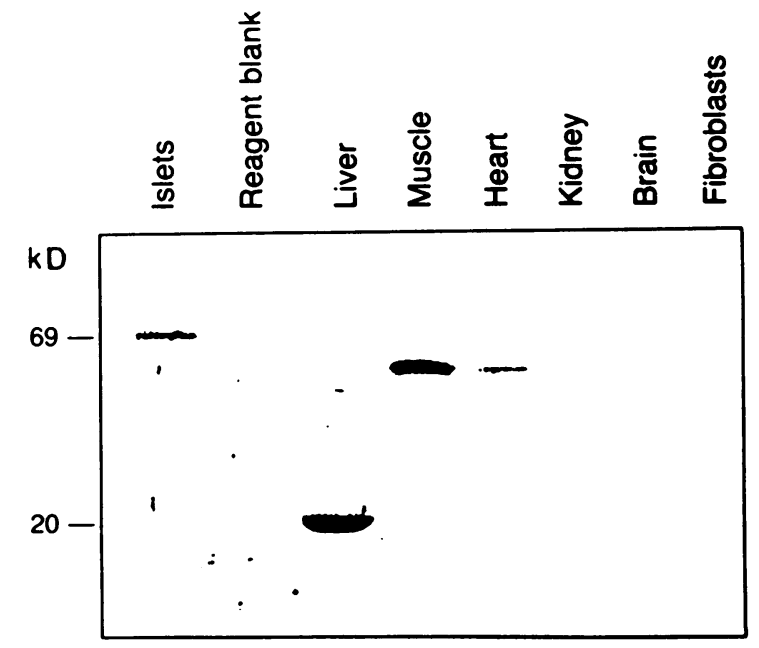

Figure 4. Western blot analysis of p69 expression in various rat tissues. Reprinted, by permission of The New England Journal of Medicine (327:306). 
onset patient sera inhibited 3-0-methyl-beta-D-glucose uptake by islets, whereas control and non-IDD patient sera did not. The inhibitory effect of IDD sera on islet cell secretion of insulin was abolished by preincubation of sera with hepatocyte membranes (which like beta cells have type 2 glucose transporter, [GLUT-2]) before the addition of sera to islet cells. However, erythrocyte membranes (containing GLUT-1 but devoid of GLUT-2) could not remove the inhibitory activity of IDD sera. However, whether these autoantibodies are directed against GLUT-2 directly or a second protein involved in the glucose transport in beta cells remains to be elucidated.

\section{Heat shock protein 65 (hsp 65)}

Two reports from one group provided evidence that a key antigenic epitope critical to the pathogenesis of IDD in NOD mice may be contained within the hsp 65 molecule $(54,55)$. In those studies, T lymphocytes specific for hsp 65 and to a contiguous 24-amino acid peptide (termed p277) transferred acute diabetes to young prediabetic NOD mice; the insulitis lesions that precede IDD in the animals contained $\mathrm{T}$ lymphocytes reactive to hsp 65 and p277; and active immunization to whole hsp 65 provoked acute diabetes. Moreover, vaccination with antip277 T lymphocytes or with p277 peptide led to decreased immunity to hsp 65 as well as prevention of insulitis and IDD (55).

With one exception, evidence to support hsp 65 as an antigen in human IDD is lacking. One study suggested that hsp 65 was the beta cell autoantigen involved in human IDD reactivity ascribed to the 64-kD autoantigen (56). Follow-up studies failed to confirm this hypothesis $(57,58)$ and showed that the 64-kD autoantigen was not cross-reactive with hsp 65. The hsp 65 protein is $60 \mathrm{kD}$ in human islet cells, and neither this nor any other identified islet cell hsp is the specific target of autoantibodies in sera from IDD patients as detected by immunoprecipitation reactions (59). Since all of these human studies were performed with autoantibodies, and are not analogous to the reported cellular studies of NOD mice, the possible pathogenic role of cellular immunity to hsp in IDD has not yet been completely resolved. Further, it still remains to be settled whether hsp 65 is an islet cell autoantigen, or whether hsp 65 (specifically p277) shares a T cell epitope with any islet cell autoantigen. It may also be important to resolve if hsp 65 is a polyclonal activator of autoreactive T cells associated with IDD, or if hsp 65 represents a superantigen unique to the murine model of the disease.

\section{Carboxypeptidase $H$}

A novel technique to identify putative islet cell autoantigens involves the immunoscreening of islet cell cDNA expression libraries with sera from IDD or pre-IDD patients. Using this technique, an autoantigen-producing clone was found to encode a fragment of carboxypeptidase $\mathbf{H}$ (enkephalin convertase) (60). Sera from $25 \%$ of ICA-positive relatives are reactive to carboxypeptidase $\mathrm{H}$, whereas controls are nonreactive to this antigen. The mRNA for this gene is also located in insulinoma lines, however, it also has been observed in human kidney, adrenal, and testes, thereby questioning its role in disease, as there is a lack of disease-restricted organ specificity to these locations of the enzyme (61). Carboxypeptidase $\mathrm{H}$ is a molecule found within islet secretory granules and neuroendocrine cells (62). It is a glycoprotein associated with the production of peptide hormones and neurotransmitters (63). This enzyme, which can be observed in both membrane-bound (majority; $52-53 \mathrm{kD}$ ) and soluble (minority; $50 \mathrm{kD}$ ) forms, facilitates the conversion of proinsulin to insulin. Carboxypeptidase $\mathrm{H}$ is a major protein of insulin secretory granules and is one of the most abundant islet cell granule proteins after proinsulin/insulin (64).

\section{Other islet cell autoantigens}

An islet cell autoantigen of $52 \mathrm{kD}$ has been identified through Western blotting analysis using rat insulinoma and human islet cell preparations $(65,66)$. The expression of this antigen is reportedly restricted to cellular membranes, and is not detectable in other endocrine/nonendocrine tissues, including adipocytes, adrenal, kidney, liver, pituitary, salivary, and testes (66). A detailed two-dimensional analysis of the $52-\mathrm{kD}$ protein revealed multiple isoforms of this antigen. Although this protein remains to be identified biochemically, an antigenic determinant of the Rubella virus capsid protein P2C is reportly shared with the $52-\mathrm{kD}$ antigen, thereby forming the basis of an inductive event in the pathogenesis based on molecular mimicry (65).

Two putative islet cell antigens, termed ICA12 and ICA512, have been identified through immunoscreening of a lambda gt 11 library containing human islet cell cDNA with IDD sera (67). Both antigens are reportedly reactive only with IDD sera, and the ICA512 antigen showed significant sequence homology with the lymphocyte common antigen CD45 (68), creating the possibility that both islet cells and CD45-positive $T$ cells could be involved in a common autoimmune process in patients with IDD.

Another novel method to detect beta cell surface antigens involved the development of a panel of mouse anti-rat insulinoma monoclonal antibodies whose binding was specific to insulinoma cells (i.e., no reactivity to rat adrenal, brain, cardiac muscle, exocrine pancreas, fibroblast [mouse], intestine, kidney, liver, ovary, pheochromocytoma, pituitary, spleen, submandibular glands, testes, thymus, and thyroid cells) (69). The ability of IDD sera to displace insulinoma reactivity by the specific monoclonal antibody was then tested. One IgM monoclonal antibody, termed 1A2, was specifically displaced by prior incubation with IDD sera but not by control sera. Although the function of the reactive antigen remains unclear, further biochemical analysis has defined the antigen to be a membrane-bound protein of $150 \mathrm{kD}$ (70). Finally, an antibody has been described that reacts with a protein antigen located at the secretory pole of transplantable rat insulinoma (RINm38) cells, and has thus been termed a "polar antigen" (71). However, its biochemical and functional description is very limited.

\section{Metabolic activity and beta cell antigenicity}

There is an increasing body of evidence derived through both in vitro and in vivo studies that suggests that the functional state (i.e., metabolic activity) of the beta cell may play a role in the pathogenesis of IDD. Prophylactic insulin administration in both humans and animal models of IDD have shown this as a potentially important method for the prevention of IDD (7274). Similarly, intensive insulin therapy in newly diagnosed IDD patients has been shown to improve subsequent beta cell function for $>1 \mathrm{yr}(75)$. Whether these beneficial effects are the result of alterations in metabolic or immunologic (or both) mechanisms is unclear. Multiple mechanisms could explain the link between beta cell destruction and functional activity, 
including increased expression of autoantigens involved in beta cell destruction, increased susceptibility to the toxic effects of mediators of beta cell destruction (e.g., IL-1, nitric oxide), and decreased ability for islet cell regeneration. In vitro evidence has supported a relationship between metabolic activity and autoantigenic expression. The cellular location of the autoantigen in question is also of interest with respect to IDD pathogenesis since granular membrane proteins are only transiently exposed on the cell surface during insulin release by exocytosis. Therefore, the accessibility of such autoantigens (e.g., $38 \mathrm{kD}$ ) to immune system components may be heightened as a result of functional hyperactivity of beta cells, while their intermittent exposure might be one means of provoking an autoimmune response.

\section{Potential for antigen-driven therapy}

The role of insulin as an agent to modify the autoimmunity observed in IDD has been explored in both humans with disease and rodent models of IDD. Most encouraging have been recent studies monitoring prophylactic injection or oral ingestion of antigens, a process that is thought to inhibit (over time) the degree of immunological responsiveness to that antigen and the organ from which that antigen derives. In non-obese diabetic mice, oral doses of insulin given intermittently from early life delays the onset of diabetes and may have inhibitory effects on the degree of insulitis (28). This beneficial effect appears to be due to an active immunoregulatory response since the preventative effect can be transferred through spenocytes in adoptive disease transfer experiments. Such effects may in turn result from the invasion of antigen-specific (e.g., insulin) $T$ lymphocytes to the pancreatic islet along with the release of transforming growth factor $\beta$ or interleukin-10. Based on these results, human trials using insulin (i.e., both prophylactic injection and oral injection) and other islet cell antigens (e.g., GAD 65) will soon begin.

Alternatively, the prophylactic administration of autoantigens through various immunization regimens has proven beneficial in preventing disease in rodent models of IDD. For example, immunization with insulin alone or in combination with adjuvants not only prevents disease, but spenocytes from these animals are capable of preventing diabetes in adoptive transfer of disease studies (our unpublished results).

\section{Summary}

A burgeoning number of antigenic targets of the islet cell autoimmunity in IDD have been identified, and more can be anticipated through improved methods for their identification. The challenge for those investigating the pathogenesis of IDD will be to assign the relative importance of these antigens to the development of the disease, and to resolve whether there is a dominant primary immunologic event that is followed by a series of secondary immunizations to a variety of normally sequestered islet cell antigens in the sequence of pathogenic events that culminate in IDD. One interesting observation that may have potential pathogenic implications is the observation that of all islet cell autoantigens described, only two (i.e., 64 $\mathrm{kD} / \mathrm{GAD}, 38 \mathrm{kD}$ ) are reactive in their native configurations, implying that recognition of conformational epitopes is most important. This property argues for primary immunizing agents rather than secondary ones after release of denatured antigens and antigenic recognition through their epitopes.
Given the complex and multiple physiological functions of islet cells and the continuous variation in their activity, it is reasonable to speculate that the speed of the progression to IDD could vary between individuals with respect to their insulin needs and the relative activities of their islets. Activated islets may express autoantigens that have only limited expression in quiescent islets. The oftentimes striking variation in the severity of insulitis seen in different islets of a single pancreas may be explained by the level of activity of individual islets. Furthermore, disparity in HLA-DR/DQ associations with disease may involve differences in the immunological recognition of autoantigens. Whereas there is still much to learn, it is clear that disease predictability and disease intervention studies have been enhanced through the identification of the islet cell autoantigens in IDD.

\section{References}

1. Bottazzo, G. F., A. Florin-Christensen, and D. Doniach. 1974. Islet cell antibodies in diabetes mellitus with autoimmune polyendocrine deficiency. Lancet. ii:1279-1283.

2. Tarn, A. C., B. M. Dean, D. Schwartz, J. M. Thomas, D. Ingram, G. F. Bottazzo, and E. A. M. Gale. 1988. Predicting insulin-dependent diabetes. Lan cet. i:845-850.

3. Bruining, G. J., J. L. Molenaar, D. E. Grobbee, A. Hofman, G. F. Scheffer, H.A Bruining, A. M. deBruyn, and H. A. Valkenburg. 1989. Ten year follow up study of islet cell antibodies and childhood diabetes. Lancet. i:1100-1102.

4. Riley, W., N. Maclaren, J. Krischer, R. Spillar, J. Silverstein, D. Schatz, S. Schwartz, J. Malone, S. Shaw, C. Valdheim, and J. Rotter. 1990. A prospective study of the development of diabetes in relatives of patients with insulin-dependent diabetes. $N$. Engl. J. Med. 323:1167-1172.

5. Nayak, R. C., M. A. K. Omar, A. Rabizadeh, S. Srikanta, and G. S. Eisenbarth. 1985. "Cytoplasmic" islet cell antibodies: evidence that the target antigen is a sialogycogonjugate. Diabetes. 34:617-619.

6. Colman, P. J., R. C. Nayak, R. C., I. L. Campbell, and G. S. Eisenbarth. 1989. Binding of cytoplasmic islet cell antibodies is blocked by human pancreatic glycolipid extracts. Diabetes. 37:645-652.

7. Dotta, F., R. Ziegler, J. O'Neill, R. C. Nayak, G. S. Eisenbarth, and M. Appel. 1989. Islet autoimmunity: identification and initial characterization of metabolically regulatable pancreatic gangliosides. Diabetologia. 19:483a. (Abstr.)

8. Solimena, M., F. Folli, R. Aparisi, G. Pozza, and P. De Camilli. 1990. Autoantibodies to GABA-nergic neurons and pancreatic beta cells in stiff-man syndrome. N. Engl. J. Med. 322:1555-1560.

9. Bottazzo, G. F., S. Genovese, E. Bosi, B. M. Dean, M. R. Christie, and E. Bonifacio. 1991. Novel consideration on the antibody/autoantigen system in type 1 (insulin-dependent) diabetes mellitus. Ann. Med. 23:453-461.

10. Gianani, R., A. Pugliese, S. Bonner-Weir, A. J. Shiffrin, J. S. Soeldner, H. Erlich, Z. Awdeh, C. A. Alper, R. A. Jackson, and G. S. Eisenbarth. 1992. Prognostically significant heterogeneity of cytoplasmic islet cell autoantibodies in relatives of patients with type 1 diabetes. Diabetes. 41:347-353.

11. Atkinson, M. A., D. L. Kaufman, L. Campbell, A. J. Tobin, and N. K. Maclaren. 1993. Islet cell cytoplasmic autoantibody reactivity to glutamate decarboxylase in insulin-dependent diabetes. J. Clin. Invest. 91:350-356.

12. Baekkeskov, S., J. H. Nielsen, B. T. Marner, J. Bilde, Ludvigsson, and A. Lernmark. 1982. Autoantibodies in newly diagnosed diabetic children immunoprecipitate human pancreatic islet cell proteins. Nature (Lond.). 298:167-169.

13. Baekkeskov, S., M. Landin, J. K. Kristensen, S. Srikanta, G. J. Bruining, T. Mandrup-Poulsen, C. de Beaufort, J. S. Soeldner, G. Eisenbarth, F. Lindgren, et al. 1987. Antibodies to $\mathrm{M}_{\mathrm{r}} \mathbf{6 4 0 0 0}$ human islet cell antigen precede the clinical onset of insulin-dependent diabetes. J. Clin. Invest. 79:926-934.

14. Atkinson, M. A., N. K. Maclaren, D. W. Scharp, P. E. Lacy, and W. J. Riley. 1990. 64,000 $\mathrm{M}_{\mathrm{r}}$ autoantibodies as predictors of insulin-dependent diabetes. Lancet. 335:1357-60.

15. Baekkeskov, S., H. Jan-Aanstoot, S. Christgau, A. Reetz, M. Solimena, M. Cascalho, F. Folli, H. Richter-Olesen, and P. De-Camilli. 1990. Identification of the $64 \mathrm{~K}$ autoantigen in insulin-dependent diabetes as the GABA-synthesizing enzyme glutamic acid decarboxylase. Nature (Lond.). 347:151-156.

16. Bu, D. F., M. G. Erlander, B. C. Hitz, N. J. K. Tillakaratne, D. L. Kaufman, C. B. Wagner-McPherson, G. A. Evans, and A. J. Tobin. 1993. Two human glutamate decarboxylases, GAD 65 and GAD 67, are each encoded by a single gene. Proc. Natl. Acad. Sci. USA. In press.

17. Erdo, S. L., and J. R. Wolff. 1990. Gamma-Aminobutyric acid outside the mammalian brain. J. Neurochem. 54:363-72. 
18. Christgau, S., H. Schierbeck, H. J. Aanstoot, L. Aagaard, K. Begley, H Kofod, K. Hejnaes, and S. Baekkeskov. 1991. Pancreatic beta cells express two forms of glutamic acid decarboxylase, a $65 \mathrm{kDa}$ hydrophilic and a $64 \mathrm{kDa}$ amphophilic form which can be both membrane bound and soluble. J. Biol. Chem 266:21257-21264.

19. Garry, D. J., H. D. Coulter, M. G. Garry, and R. L. Sorenson. 1988 Immunoreactive immunolocalization of L-glutamate decarboxylase in rat pancreatic islets. J. Histochem. Cytochem. 36:573-80.

20. Peterson, J. S., S. Russel, M. O. Marshall, H. Kofod, K. Buschard, A. E Cambon, A. E. Karlsen, E. Boel, W. A. Hagopian, K. R. Hejnaes, A. Moody, T. Dyrberg, A. E. Lernmark, O. D. Madsen, and B. K. Michelsen. 1993. Differentia expression of glutamate decarboxylase in rat and human islets. Diabetes. 42:484495

21. Karlsen, A. E., W. A. Hagopian, J. S. Petersen, E. Boel, T. Dyrberg, C. E. Grubin, B. K. Michelsen, O. D. Madsen, and A. Lernmak. 1992. Recombinant glutamic acid decarboxylase (representing the single isoform expressed in human islets) detects IDDM-associated 64,000 $\mathrm{M}_{\mathrm{r}}$ autoantibodies. Diabetes 41:13551359

22. Kaufman, D. L., M. G. Erlander, M. Clare-Salzler, M. A. Atkinson, N. K Maclaren, and A. J. Tobin. 1992. Autoimmunity to two forms of glutamate decarboxylase in insulin-dependent diabetes mellitus. J. Clin. Invest. 89:283-92.

23. Atkinson, M. A., D. L. Kaufman, L. Campbell, K. A. Gibbs, S. C. Shah, D.-F. Bu, M. G. Erlander, A. J. Tobin, and N. K. Maclaren. 1992. Response of peripheral-blood mononuclear cells to glutamate decarboxylase in insulin-dependent diabetes. Lancet. 339:458-459.

24. Palmer, J. P., C. M. Asplin, P. Clemons, K. Lyen, O. Tapati, P. Raghu, and T. L. Pauquette. 1982. Insulin autoantibodies in insulin-dependent diabetes before insulin treatment. Science (Wash. DC). 222:1337-1338.

25. Atkinson, M. A., N. K. Maclaren, W. J. Riley, W. E. Winter, D. D. Fisk, and R. P. Spillar. 1986. Are insulin autoantibodies markers for insulin-dependent diabetes mellitus? Diabetes. 33:894-897.

26. Srikanta, S., A. T. Ricker, D. K. McCulloch. J. S. Soeldner, G. S. Eisenbarth, and J. P. Palmer. 1986. Autoimmunity to insulin, beta cell dysfunction, and development of insulin-dependent diabetes mellitus. Diabetes. 35:139-143.

27. Vardi, P., A. G. Ziegler, J. H. Matthews, S. Dib, R. J. Keller, A. T. Ricker J. L. Wolfsdorf, R. D. Herskowitz, A. Rabizada, G. S. Eisenbarth, and J. S. Soeldner. 1988. Concentration of insulin autoantibodies at onset of type 1 diabetes: inverse log-linear correlation with age. Diabetes Care. 11:736-740.

28. Zhang, Z. J., L. Davidsen, G. S. Eisenbarth, H. L. Weiner, and R. S. Weiner. 1991. Suppression of diabetes in non obese diabetic mice by oral administration of porcine insulin. Proc. Natl. Acad. Sci. USA 88:10252-10256.

29. Diaz, J. L., and T. Wilkin. 1987. Differences in epitope restriction of autoantibodies to native human insulin (IAA) and antibodies to heterologous insulin (IA). Diabetes. 36:66-72.

30. Livneh, A., H. Avraham, D. Elias, J. Sack, I. R. Cohen, and Z. Eshhar. 1986. A human monoclonal antibody to insulin. Diabetes. 35:68-73.

31. Uchigata, Y., K. Yao, S. Takayama-Hasumi, and Y. Hirata. 1989. Human monoclonal IgG1 insulin autoantibody from insulin autoimmune syndrome directed at determinant at asparagine site on insulin B-chain. Diabetes. 38:663-666.

32. Foggensteiner, L., A. J. Bone, K. A. Webster, and T. J. Wilkin. 1990. Increased preproinsulin mRNA in pancreatic islets incubated with islet cell-stimulating autoantibodies from serums of type 1 diabetes patients. Diabetes. 39:11651169.

33. Storch, M. J., T. Licht, K. G. Petersen, R. Obermeier, and L. Kerp. 1987. Specificity of monoclonal anti-human insulin antibodies. Diabetes. 36:10051009.

34. Bohmer, K., H. Keilacker, B. Kuglin, A. Hubinger, J. Bertrams, F. A. Gries, and H. Kolb. 1991. Proinsulin autoantibodies are more closely associated with type 1 (insulin-dependent) diabetes mellitus than insulin autoantibodies. Diabetologia. 34:830-834.

35. Heding, L. G., J. Ludvigsson, and T. Kasperska-Czyzykowa. 1982. Beta cell secretion in non-diabetics and insulin-dependent diabetics. Acta Med. Scand. 656:5-9.

36. Hartling, S. G., F. Lindgren, G. Dahlquist, B. Persson, and C. Binder 1989. Elevated proinsulin in healthy subject of IDDM patients independent of HLA identity. Diabetes. 38:1271-1274.

37. Keller, R. J. 1990. Cellular immunity to human insulin in individuals at high risk for the development of type 1 diabetes mellitus. J. Autoimmun. 3:321327

38. Harrison, L. C., H. Aizpurua, T. Loudovaris, I. L. Campbell, J. S. Cebon, B. D. Tait, and P. G. Colman. 1991. Reactivity to human islets and fetal pig proislets by peripheral blood mononuclear cells from subjects with preclinical and clinical insulin-dependent diabetes. Diabetes. 40:1128-1133.

39. Miller, G. G., M. S. Pollack, L. J. Nell, and J. W. Thomas. 1987. Insulinspecific human $\mathrm{T}$ cells. Epitope specificity, major histocompatibility complex restriction, and alloreactivity to a diabetes-associated haplotype. J. Immunol. 139:3622-3629.
40. Maron, R., D. Elias, H. deJong, J. Bruning, J. J. van Rood, Y. Schechter, and I. R. Cohen. 1984. Autoantibodies to the insulin receptor in juvenile-onset diabetes. Nature (Lond.). 303:817-819.

41. Rochet, N., J. L. Sadoul, B. Ferrua, J. Kubar, J. F. Tanti, P. Bougneres, B. Vialettes, E. Van-Obberghen, Y. Le-Marchand, and P. Freychet. 1990. Autoantibodies to the insulin receptor are infrequent findings in type 1 diabetes mellitus of recent onset. Diabetologia. 33:411-416.

42. Van Vliet, E., B. O. Roep, L. Meulenbroek, G. J. Bruining, and R. R. P. De Vries. 1989. Human T cell clones with specificity for insulinoma cell antigens. Eur. J. Immunol. 19:213-216.

43. Roep, B. O., S. D. Arden, R. R. De Vries, and J. C. Hutton. 1990. T-cell clones from a type 1 diabetes patient respond to insulin secretory granule proteins. Nature (Lond.). 345:632-634.

44. Roep, B. O., A. A. Kallan, W. L. W. Hazenbos, G. J. Bruining, E. M. Baileys, S. D. Ardern, J. C. Hutton, and R. R. P. De Vries. 1991. T cell reactivity to $38 \mathrm{kD}$ insulin-secretory-granule protein in patients with recent-onset type 1 diabetes. Lancet. 337:1439-1441.

45. Maclaren, N. K., and M. A. Atkinson. 1992. Is insulin-dependent diabetes environmentally induced? N. Engl. J. Med. 327:348-349.

46. Virtanen, S. M., L. Rasanen, A. Aro, J. Lindstrom, J. Lindstrom, J. Tuomilehto, and H. K. Akerbloom. 1991. I. Infant feeding in Finnish children less than $7 \mathrm{yr}$ of age with newly diagnosed IDDM. Childhood diabetes in Finland study group. Diabetes Care. 14:415-417.

47. Borch-Johnsen, K., G. Joner, T. Mandrup-Poulsen, M. Christy, B. Zachau-Christiansen, K. Kastrup, and J. Nerup. 1984. Relationship between breast feeding and indicence rates of IDDM. Lancet. ii: 1084 .

48. Dahl-Jorgensen, K., G. Joner, and K. F. Hanssen. 1991. Relationship between cow's milk consumption and incidence of IDDM in childhood. Diabetes Care. 14:1081-1083

49. Colman, P. G., I. L. Campbell, T. W. Kay, and L. C. Harrison. 1987. $64,000 \mathrm{M}_{\mathrm{r}}$ autoantigen in type 1 diabetes. Evidence against its surface location on human islets. Diabetes. 36:1432-1440.

50. Savilahti, E., H. K. Akerblom, and S. Koskimies. 1988. Children with newly diagnosed insulin-dependent diabetes mellitus have increased levels of cows' milk antibodies. Diabetes Res. 7:137-40.

51. Glerum, M., B. H. Robinson, and J. M. Martin. 1989. Could bovine serum albumin be the initiating antigen ultimately responsible for the development of insulin-dependent diabetes mellitus? Diabetes Res. 10:103-107.

52. Karjalainen, J., J. M. Martin, M. Knip, J. Ilonen, B. H. Robinson, E. Savilahti, H. K. Akerblom, and H. M. Dosch. 1992. A bovine albumin peptide as a possible trigger of insulin-dependent diabetes mellitus. N. Engl. J. Med. 327:302-307.

53. Johnson, T. H., B. P. Crider, K. McCorkle, M. Alford, and R. H. Unger. 1990. Inhibition of glucose transport into rat islet cells by immunoglobulins from patients with new-onset insulin-dependent diabetes mellitus. $N$. Engl. J. Med. 322:653-659.

54. Elias, D., D. Markovits, T. Reshef, R van der Zee, and I. R. Cohen. 1990. Induction and therapy of autoimmune diabetes in the non-obese diabetic mouse by a $65-\mathrm{kDa}$ heat shock protein. Proc. Natl. Acad. Sci. USA. 87:1576-1580.

55. Elias, D., T. Reshef, o. Birk, R. Van der Zee, M. D. Walker, and I. R. Cohen. 1991. Vacination against autoimmune mouse diabetes with a T-cell epitope of the human $65-\mathrm{kDa}$ heat shock protein. Proc. Natl. Acad. Sci. USA. 88:3088-3091.

56. Jones, D. B., N. R. Hunter, and G. W. Duff. 1990. Heat shock protein 65 as a $\beta$ cell antigen of insulin-dependent diabetes. Lancet. 335:583-585.

57. Atkinson, M. A., N. K. Maclaren, and D. W. Scharp. 1990. No role for $65 \mathrm{kD}$ heat-shock protein in diabetes. Lancet. 336:1250-1251.

58. Kampe, O., L. Velloso, A. Andersson, and A. Karlsson. 1990. No role for $65 \mathrm{kD}$ heat-shock protein in diabetes. Lancet. 336:1250.

59. Atkinson, M. A., L. A. Holmes, D. W. Sharp, P. E. Lacy, and N. K Maclaren. 1991. No Evidence for serological autoimmunity toward islet cell heat shock proteins in insulin-dependent diabetes. J. Clin. Invest. 7:721-724.

60. Castano, L., E. Russo, L. Zhou, M. A. Lipes, and G. Eisenbarth. 1991. Identification and cloning of a granule autoantigen (Carboxypeptidase- $\mathrm{H}$ ) associated with type 1 diabetes. J. Clin. Endocrinol. \& Metab. 73:1197-1201.

61. Powers, A., S. Bowen, and S. West. 1991. Carboxypeptidase-H is an autoantigen of the ICA and is expressed on the cell surface of islet cells. Diabetes. 40:1a. (Abstr.)

62. Suppattapone, S., L. D. Fricker, and S. H. Snyder. 1984. Purification and characterization of a membrane bound enkephalin-forming carboxypeptidase, "enkephalin convertase." J. Neurochem. 42:1017-1023.

63. Davidson, H. W., C. J. Rhodes, and J. C. Hutton. 1988. Intraorganellar calcium and $\mathrm{pH}$ control proinsulin clevage in the pancreatic $\mathrm{A}$ cell via two distinct site-specific endopeptidases. Nature (Lond.). 33:93-96.

64. Hutton, J. C. 1989. The insulin secretory granule. Diabetoloigia. 32:271-

65. Karounos, D. G., J. S. Wolinsky, B. K. Gillard, and J. W. Thomas. 1990. 
Molecular mimicry in type 1 diabetes: an antigenic determinant on a rubella virus protein is shared with a 52kD beta cell autoantigen. Diabetes. 39:96a. (Abstr.)

66. Karounos, D. G., and J. W. Thomas. 1990. Recognition of common islet antigen by autoantibodies from NOD mice and humans with IDDM. Diabetes. 39:1085-1090.

67. Rabin, D. U., S. M. Pleasic, R. Palmer-Crocker, and J. A. Shapiro. 1992. Cloning and expression of IDDM specific human autoantigens. Diabetes. 41:183-186.

68. Rabin, D., S. Pleasic, R. Palmer-Crocker, P. M. M. Rae, J. Shapiro, J. Barbosa, W. Knowles, C. Rowe, and J. Oles. 1991. Cloning and Expression of islet cell autoantigens. Diabetes. 40:1 a. (Abstr.)

69. Thomas, N. M., F. Ginsberg-Fellner, and R. C. McEvoy. 1990. Strong association between diabetes and displacement of mouse anti-rat insulinoma cell monoclonal antibody by human serum in vitro. Diabetes. 39:1203-1211.

70. Kohtz, J. D., N. M. Thomas, R. Ginsberg-Fellner, and R. C. McEvoy. 1990. A novel beta cell plasma membrane antigen associated with anti-pancreatic autoimmunity in insulin-dependent diabets mellitus (IDDM). Diabetes. 39:122a. (Abstr.)

71. Dotta, F., L. Wicker, L. Peterson, M. Pressley, M. Appel, and G. S. Eisenbarth. 1989. Inheritance of "anti-polar" antibodies in the NOD mouse: evidence for a single recessive gene. Diabetes. 38:76a. (Abstr.)

72. Gotfredsen, C. F., K. Buschard, and E. K. Frandsen. 1985. Reduction of diabetes incidence of BB Wistar rats by early prophylactic insulin treatment of diabetes prone animals. Diabetologia. 28:933-37.

73. Atkinson, M. A., N. K. Maclaren, and R. Luchetta. 1990. Insulitis and diabetes in NOD mice reduced by prophylactic insulin administration. Diabetes. 39:933-937.

74. Keller, R. J., R. A. Jackson, and G. S. Eisenbarth. 1992. Preservation of beta cell function in islt cell antibody positive first degree relatives treated with insulin. Diabetes. 41:13a. (Abstr.)

75. Shah, S., J. Malone, and N. E. Simpson. 1989. A randomized trial of intensive insulin therapy in newly diagnosed insulin-dependent diabetes mellitus. N. Engl. J. Med. 320:540-544. 